
\title{
25 Research Square \\ The clinical significance of serum free DNA concentration detection in patients with schizophrenia
}

Ling-yun Chen ( $\nabla 1062975260 @ q q . c o m$ )

Nantong Mental Health Center

Jing Qi

Affiliated Hospital of Nantong University

Hong-lei Xu

Affiliated Hospital of Nantong University

Xiang-yun Lin

Nantong University

Ya-jun Sun

Nantong Mental Health Center

Shao-qing Ju

Affiliated Hospital of Nantong University

Research article

Keywords: schizophrenia, circulating cell-free DNA, Alu

Posted Date: March 9th, 2020

DOl: https://doi.org/10.21203/rs.3.rs-16334/v1

License: (9) (i) This work is licensed under a Creative Commons Attribution 4.0 International License.

Read Full License 


\section{Abstract}

Background: Cell-free DNA(cf-DNA) has been described as an effectived biomarker in autoimmune disease, which mainly due to the release of apoptotic cells. In this study, we hypothesized and explored the relationship between cf-DNA and the influencing factors of the appearance and development of schizophrenia, so as to provide the basis for further research, prevention and treatment. Methods: We analysed and compared the concentration of cf-DNA in 174 schizophrenia patients and matched 100 healthy controls using quantitative real-time PCR by amplifying the Alu repeats. Results: We found that cf-DNA levels in peripheral blood reliably distinguished schizophrenia from a normal control group. In addition, we found by tracking the median absolute concentration of serum cf-DNA in primary cases, we found a distinct increase at prior treatment and it then decreased progressively at post treatment. Conclusions: Our study quantified cf-DNA in SZ patients serum by using conventional RT-qPCR. The detection of cf-DNA concentration was valuable for monitoring disease duration of SZ patients and laid a foundation for the study of the molecular mechanism of SZ disease. Keywords: schizophrenia, circulating cell-free DNA, Alu

\section{Background}

Schizophrenia is a major public problem, presenting high damage to the brain function, characteristics that affect about $1 \%$ of the world population [1-3]. Different from many other diseases, the exact aetiology and pathogenesis of SZ remains elusive. So far there is no definite laboratory examination or laboratory test results to support clinical diagnosis as the basis for diagnosis. According to the assessment of some scales and laboratory tests, doctors assist in diagnosis and determine the severity for reference. The determination of diagnosis still depends on the medical history, combined with the law of mental symptoms and disease progression. And these assessments are subject to subjective factors. Due to our limited understanding of the origin and pathogenesis of the disease, we have not yet maken the full use of these changes as a potential biomarker and therapeutic targets [4]. Therefore, development of diagnostic and prognostic biomarkers is an urgent task.

Cf-DNA was first observed by French scientists Mandel and Metais in human plasma in 1948 [5]. After that, Leon found that the content of cf-DNA in blood increased in patients with malignant tumors in 1977, the study on the correlation between cf-DNA in blood and tumors has become a hot topic [6], causing indepth studies by many scholars. Now it is generally believed that cf-DNA is mainly derived from apoptosis and necrosis [7-9], which is a kind of cell-free extracellular DNA. While there are some hypothesis about the causes of schizophrenia have been proposed, including abnormal neurotransmitter, development or nerve generation process and immune system disorders [10], etc, but it cannot fully explain the hypothesis of schizophrenia. Moreover, apoptosis is a physiological process of cell death and has been confirmed to be involved in the pathological process of schizophrenia. Pro-apoptotic stimulation such as inflammation, autoimmune and oxidative stress may lead to the accumulation of ROS in mitochondria, affect the oxidative metabolic process, and then trigger the apoptosis of nerve cells and glial cells [11-13]. Early studies have shown that $20-80 \%$ of nerve cells in the central nervous 
system die from apoptosis [14] and reported the aberration of apoptosis regulatory protein and DNA fragmentation status in the posterior temporal cortex $[15,16]$. Besides that, abnormal tumor vasculature can develop early in tumor development, and many of the same abnormalities have been reported in the reports of vascular abnormalities in schizophrenia, such as abnormal levels of endothelial cell proliferation and apoptosis [17-19]. As mentioned above, these studies laid the foundation for exploring the potential role of apoptosis in schizophrenia and apoptosis of dysfunctional cells may be involved in the pathogenesis of schizophrenia. However, early reports did not assess specific markers of apoptotic cells, and thus did not suggest large-scale cell loss in patients with schizophrenia [20]. Based on the above viewpoints, it is very interesting to explore whether apoptosis occurs and its potential activation mechanism, and lay the foundation for exploring the potential role of cf-DNA in schizophrenia.

Wang [21] found that long DNA fragments associated with necrosis could be distinguished from short DNA fragments, generated by physiological apoptosis using PCR. In the current study, we investigated the serum expression level of cf-DNA in SZ patients and explored its clinical value as a serum auxiliary biomarker for early diagnosis and prognosis prediction of SZ. In this study, we detected the Alu content in SZ and the normal control group, and found that the Alu content in SZ group was significantly higher than that in the control group. We analyzed the Alu level and clinical data of SZ, and found that Alu was no correlated with age at onset, duration of psychosis and pharmacological treatment. This study will lay a foundation for the pathogenesis and searching for feasible biomarkers of schizophrenia. The study can contribute to a better understanding of psychosis aetiology and improve the accuracy of psychiatric diagnosis.

\section{Methods}

\section{Subjects}

Serum samples were collected at from 174 patients with schizophrenia (the SZ group) who were from the Nantong Fourth Peoples Hospital, from 1st December 2017 to 1st August 2018. SZ patients were divided into undifferentiated type (133), paranoid (11), acute schizophrenia-like psychosis (29), and other subtypes (2). The diagnosis of schizophrenia was based on the criteria of Diagnostic and Statistical Manual of Mental Disorders, Four Edition.

And 100 healthy controls (the $\mathrm{HC}$ group) were collected during the same period from the Physical Examination Center of the Afiliated Hospital of Nantong University (Nantong, China). Controls were matched with the patients by sex and age. Exclusion criteria were: history of neurological disease or brain trauma, history of cancer, history of lifelong drug/alcohol dependence or recent drug abuse, and history of pregnancy in women. The dmographic details of participants for all the subjects are shown in supplementary Table 1.

\section{Clinical Assessment}


We used the Nottingham Onset Schedule to record the onset date of the psychotic symptom and the beginning of pharmacological treatment. Pharmacological treatment duration was defined by the period, in weeks, between the beginning of pharmacological treatment and blood collection. Finally, the interval, in weeks, between the date of the psychotic symptoms first manifestation and blood collection date defined the total duration of the metal disorder.

Age of onset of symptoms was collected for all patients with schizophrenia. In addition, the positive and negative syndrome scale (PANSS) was used for all clinical participants.

Plasma collection and cf-DNA isolation

Blood samples were collected in separating gel vacuum collection tubes and centrifuged at $3000 \times \mathrm{g}$ for $10 \mathrm{~min}$. The upper-layer supernatant was immediately stored in an RNase-free Eppendorf tube at $-80^{\circ} \mathrm{C}$ until use. Cf-DNA was extracted from $0.2 \mathrm{ml}$ of serum using the TIANLONG DNA Kit (Suzhou, China) according to the manufacturer's protocol.

\section{Quantitative Real-time Polymerase Chain Reaction (rt-qpcr)}

RT-qPCR was performed on Applied Biosystems 7500 (Applied Biosystems, CA, USA). We performed experiment with absolute quantification to verify the results. The target for RT-qPCR was the consensus sequence of human Alu-interspersed repeats: a 115 bp Alu amplicon (Alu115) that represents both shorter and longer cf-DNA fragments. The diluted cf-DNA template was used with $1 \times$ FastStart Universal SYBR Green $₫$ master mix (Roche, Switzerland) for RT-qPCR, which was performed by Real-Time PCR System (Life Technologies, USA) at $95^{\circ} \mathrm{C}$ for 10 min, followed 35 cycles of denaturation at $95^{\circ} \mathrm{C}$ for $15 \mathrm{~s}$, annealing at $64^{\circ} \mathrm{C}$ for $1 \mathrm{~min}$ [22]. The absolute level of Alu is quantified using the standard curve (from 0.222 to $22200 \mathrm{ng} / \mathrm{ml}$ ) of human genome DNA (Promega, Madison, WI, USA). And mean values were calculated from triplicate reactions.

\section{Detection Of Biochemical Indicators}

The liver function, kidney function, blood glucose, electrolyte, cardiac enzyme spectrum and lipid profile of 174 patients were detected on Olympus AU680 biochemical analyzer.

\section{Statistical analysis}

The concentration of Alu is the median of the 25th percentile and the 75th percentile. Statistical analysis was performed using the SPSS software package version 20.0 (SPSS Inc., Chicago, USA). Statistical significance was tested by a Mann Whitney unpaired test analysis of variance or a Chi-square test as appropriate. $\mathrm{P}<0.05$ was considered statistically significant. Receiver operating characteristic (ROC) curves and area under the ROC curve (AUC) were used to assess the diagnostic value of using SZ. The 
maximum AUC area is determined by the specificity and sensitivity of the optimal cut-off point. The figures were partially drawn by GraphPad Prism 5.0 software (Graphpad Software Inc., CA, USA)

\section{Results}

Cf-DNA levels measured by RT- qPCR

In this study, we detected cf-DNA using RT-qPCR of 115 bp amplicons. 174 patients with schizophrenia (the SZ group) were from the Nantong Mental Health Center. And 100 healthy controls (the HC group) were collected during the same period from the Physical Examination Center of the Afiliated Hospital of Nantong University (Nantong, China). Consistently, the average concentration of cf-DNA in SZ patients and healthy people were respectively $586.0 \mathrm{ng} / \mathrm{ml}$ (interquartlie range 228.4-1275.7 ng/ml) and $318.3 \mathrm{ng} / \mathrm{ml}$ (interquartlie range $253.5-427.4 \mathrm{ng} / \mathrm{ml}$ ). The average concentration of cf-DNA significantly increased in SZ group compared with in the HC group $(P<0.05)$ (Fig. 1). SZ patients were divided into undifferentiated type (133), paranoid (11), acute schizophrenia-like psychosis (29), and other subtypes (2). The average concentration of cf-DNA in the different types were respectively $533.5 \mathrm{ng} / \mathrm{ml}$ (interquartlie range $237.1-1095.9 \mathrm{ng} / \mathrm{ml}$ ), $849.9 \mathrm{ng} / \mathrm{ml}$ (interquartlie range $450.5-1378.6 \mathrm{ng} / \mathrm{ml}$ ) and $1115.3 \mathrm{ng} / \mathrm{ml}$ (interquartlie range $167.1-1673.4 \mathrm{ng} / \mathrm{ml}$ ). And there was no statistical difference between the groups (Fig. 3). $(P>0.05)$

\section{Diagnostic Utility Of Serum Cf-dna In Sz Patients}

To investigate characteristics of serum of cf-DNA as a potential maker for SZ, receiver operating characteristics (ROC) curves were constructed on date from all subjects, including $174 \mathrm{SZ}$ patients and 100 healthy controls. Serum cf-DNA effectively differentiated SZ patients from normal controls with an area under the ROC curves (AUC) of 0.6787 , with a $95 \%$ confidence interval of $61.66 \%-74.08 \%$ (Fig. 2). When the cut-off value was $567.1 \mathrm{ng} / \mathrm{ml}$, the sensitivity was $51.72 \%$ and the specificity was $90 \%$, with a $95 \%$ confidence interval of $44.04 \%-59.35 \%$. SZ patients were divided into undifferentiated type (133), paranoid (11), acute schizophrenia-like psychosis (29), and other subtypes (2). Based on the cut-off value of $567.1 \mathrm{ng} / \mathrm{ml}$, there is undifferentiated type $63(47.7 \%)$, the paranoid $8(72.7 \%)$, acute schizophrenia like psychosis 19 (65.6\%), no statistical differences between different classification groups $(P>0.05)$ (Fig. 3).

Analysis of the correlation between Alu and clinical data in SZ patients

We examined for the potential effect of clinical features on change in cf-DNA. The analysis of the effect of the cf-DNA levels on clinical variables like age at onset, duration of psychosis and pharmacological treatment revealed no statistically significant correlation between any of the clinical parameters and cfDNA level $(P>0.05)$ (Table 2). 
Table 1

Demographic details of participants

\begin{tabular}{|lll|}
\hline & Healthy individuals & SZ patients \\
\hline Total Number[N] & 100 & 174 \\
\hline Sex [M:F] & $47: 53$ & $90: 84$ \\
\hline Age (years) & 34.8 & 27.1 \\
\hline
\end{tabular}


Table 2

Clinical features of patients of SZ $(n=174)$ according to the specific diagnostic categories

\begin{tabular}{|c|c|c|c|}
\hline & $\mathbf{N}$ & $\begin{array}{l}\text { Alu Median (interquartile range) } \\
(\mathrm{ng} / \mathrm{ml})\end{array}$ & P-value \\
\hline Total & 174 & $586.0(228.4-1275.7)$ & \\
\hline Gender & & & 0.3816 \\
\hline Male & $90(51.7 \%)$ & $535.4(228.4-1092.4)$ & \\
\hline Female & $84(48.3 \%)$ & $625.0(275.6-1415.6)$ & \\
\hline Psychosis onset age (y) & & & 0.9418 \\
\hline Up to 16 & $39(22.4 \%)$ & $609.6(256.9-1412.4)$ & \\
\hline 17 to 24 & 77 (44.3\%) & $634.3(296.6-1197.6)$ & \\
\hline 25 to 34 & $47(27.0 \%)$ & $591.3(220.2-1331.0)$ & \\
\hline 35 or more & $11(6.3 \%)$ & $872.0(353.0-1251.1)$ & \\
\hline Current age (y) & & & 0.3299 \\
\hline 13 to 24 & $85(48.9 \%)$ & 776.7 (343.7-1430.1) & \\
\hline 25 to 34 & $60(34.5 \%)$ & $631.8(296.6-1113.4)$ & \\
\hline 35 or more & $29(16.7 \%)$ & $422.8(210.5-1114.7)$ & \\
\hline $\begin{array}{l}\text { Duration of psychosis (in } \\
\text { weeks) }\end{array}$ & & & 0.2301 \\
\hline Up to 12 & $42(24.1 \%)$ & $849.9(318.2-1673.5)$ & \\
\hline 13 to 52 & $28(16.1 \%)$ & $687.2(346.8-2093.1)$ & \\
\hline 53 or more & $\begin{array}{l}104 \\
(59.8 \%)\end{array}$ & $576.7(254.2-1113.4)$ & \\
\hline Current treatment & & & 0.6479 \\
\hline AP & $\begin{array}{l}133 \\
(76.4 \%)\end{array}$ & $650.6(240.3-1326.4)$ & \\
\hline$A P+A D$ & $19(10.9 \%)$ & $671.1(465.3-1601.1)$ & \\
\hline $\mathrm{AP}+\mathrm{MS}$ & $22(12.6 \%)$ & $767.9(463.3-1156.0)$ & \\
\hline Family history & & & 0.4306 \\
\hline Yes & $17(9.8 \%)$ & $1015.1(414.9-1279.0)$ & \\
\hline
\end{tabular}

$P<0.05$ was considered statistically significant. 


\begin{tabular}{|l|l|l|}
\hline & N & $\begin{array}{l}\text { Alu Median (interquartile range) } \\
(\mathbf{n g} / \mathrm{ml})\end{array}$ \\
\hline No & 157 & $584.5(225.6-1275.5)$ \\
\hline $\mathrm{P}<0.05$ was considered statistically significant. & \\
\hline
\end{tabular}

This study also tested the correlation between Alu and CGI score, abandonment score, attack score and PANSS scale score of SZ patients, and found that there was statistically significant between Alu and SZ patients' CGI score $(P<0.05)$, but no significant difference with other scores $(P>0.05)$ (Table 3$)$.

Table 3

Correlation analysis between Alu and scores in patients with psychiatric disorders

\begin{tabular}{|lcc|}
\hline & \multicolumn{2}{|c|}{ Alu (ng/ml) } \\
\cline { 2 - 3 } & $\mathbf{r}$ & $\mathbf{P}$ \\
\hline CGI score & 0.1638 & 0.0499 \\
\hline Abandon score & -0.1286 & 0.1258 \\
\hline Attack score & 0.01357 & 0.8718 \\
\hline Positive syndrom scale totle score & 0.038 & 0.6690 \\
\hline Negtive syndrom scale totle score & -0.1008 & 0.2555 \\
\hline P $<0.05$ was considered statistically significant \\
\hline
\end{tabular}

Analysis of the correlation between Alu and biochemical indexes in SZ patients

We analyzed the correlation between the concentration of cf-DNA and biochemical indexes and revealed no statistically significant correlation between any of the clinical parameters and cf-DNA level $(P>0.05)$ except RBP, Cyc and NEFA (Table 4). 
Table 4

Correlation analysis between the concentration of the Alu and biochemical indexes

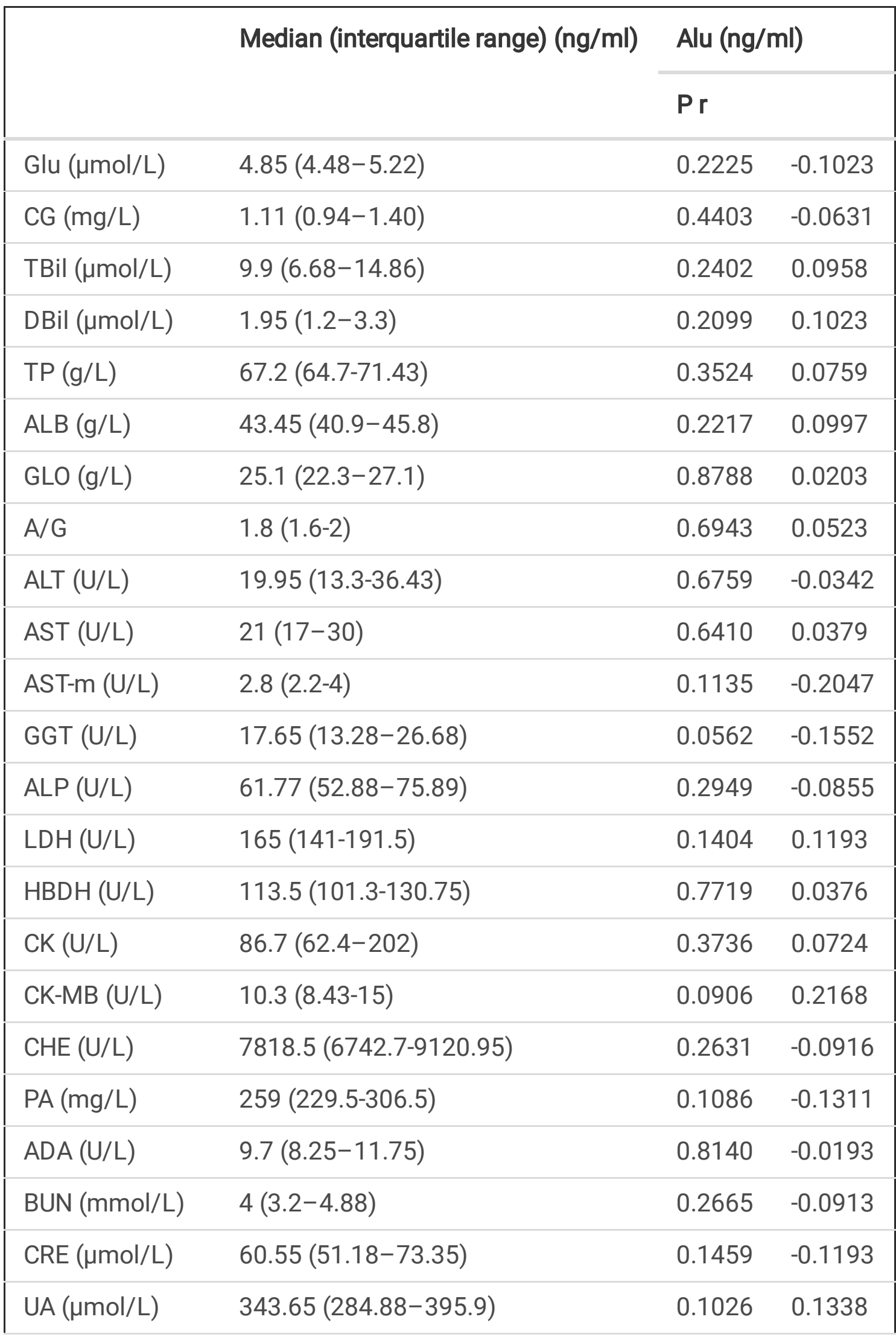

$\mathrm{P}<0.05$ was considered statistically significant. 


\begin{tabular}{|llll|}
\hline & Median (interquartile range) $(\mathrm{ng} / \mathrm{ml})$ & \multicolumn{2}{l|}{ Alu $(\mathrm{ng} / \mathrm{ml})$} \\
\cline { 3 - 4 } & & $\mathrm{P} \mathrm{r}$ & \\
\hline $\mathrm{B} 2 \mathrm{MG}(\mathrm{mg} / \mathrm{L})$ & $1.33(1.06-1.62)$ & 0.2869 & -0.0875 \\
\hline $\mathrm{RBP}(\mathrm{mg} / \mathrm{L})$ & $34.6(27.9-40.1)$ & 0.0128 & -0.2035 \\
\hline $\mathrm{Cyc}(\mathrm{mg} / \mathrm{L})$ & $0.54(0.48-0.61)$ & 0.0231 & -0.1860 \\
\hline $\mathrm{K}(\mathrm{mmol} / \mathrm{L})$ & $4.06(3.81-4.28)$ & 0.1855 & 0.1083 \\
\hline $\mathrm{Na}(\mathrm{mmol} / \mathrm{L})$ & $141.32(139.68-143.12)$ & 0.5086 & 0.0542 \\
\hline $\mathrm{Cl}(\mathrm{mmol} / \mathrm{L})$ & $101(99.11-103.57)$ & 0.4231 & 0.0657 \\
\hline $\mathrm{Ca}(\mathrm{mmol} / \mathrm{L})$ & $2.29(2.24-2.35)$ & 0.2692 & 0.0905 \\
\hline $\mathrm{P}(\mathrm{mmol} / \mathrm{L})$ & $1.24(1.1-1.37)$ & 0.1033 & -0.1331 \\
\hline $\mathrm{Mg}(\mathrm{mmol} / \mathrm{L})$ & $0.83(0.77-0.88)$ & 0.2439 & 0.0954 \\
\hline $\mathrm{COQ}(\mathrm{mmol} / \mathrm{L})$ & $24.89(23.02-27.50)$ & 0.0139 & -0.1999 \\
\hline $\mathrm{CHOL}(\mathrm{mmol} / \mathrm{L})$ & $3.98(3.44-4.64)$ & 0.8987 & -0.0120 \\
\hline $\mathrm{TG}(\mathrm{mmol} / \mathrm{L})$ & $1.07(0.80-1.36)$ & 0.0692 & -0.1693 \\
\hline $\mathrm{HDL}(\mathrm{mmol} / \mathrm{L})$ & $1.19(1.00-1.38)$ & 0.7300 & 0.0324 \\
\hline $\mathrm{LDL}(\mathrm{mmol} / \mathrm{L})$ & $2.11(1.76-2.54)$ & 0.7871 & 0.0253 \\
\hline $\mathrm{APOA} 1(\mathrm{~g} / \mathrm{L})$ & $1.09(0.99-1.20)$ & 0.9840 & 0.0019 \\
\hline $\mathrm{APOB}(\mathrm{g} / \mathrm{L})$ & $0.73(0.63-0.87)$ & 0.9392 & -0.0072 \\
\hline $\mathrm{APOE}(\mathrm{mg} / \mathrm{L})$ & $40.45(37.33-45.25)$ & -0.0724 \\
\hline $\mathrm{LP}(\mathrm{a})(\mathrm{mg} / \mathrm{L})$ & $132.1(63.2-260.35)$ & -0.0561 \\
\hline $\mathrm{NEFA}(\mu \mathrm{mol} / \mathrm{L})$ & $580.5(291.53-832.05)$ & 0.2072 \\
\hline $\mathrm{P}<0.05 \mathrm{was} \mathrm{cons})$ & & \\
\hline
\end{tabular}

\section{Dynamic Monitoring Of Serum Cf-dna In Sz Patients}

Next, we investigated the expression of cf-DNA in 57 newly diagnosed SZ patients. The median absolute serum cf-DNA in 57 newly diagnosed cases increased at prior treatment $(1040.4 \mathrm{ng} / \mathrm{ml}, 388.3$ $1673.4 \mathrm{ng} / \mathrm{ml}$ ) compared with HC group, and which is higher than the Alu level at post treatment (366.3 ng/ml, $173.3 \sim 815.7 \mathrm{ng} / \mathrm{ml}$ ). As shown in Fig. 4, serum cf-DNA dynamically varied in these patients. These data suggest that serum cf-DNA predicted the remedial effect for SZ patients. 


\section{Discussion}

Recent studies have shown that molecular abnormalities in the expression of many mental disorders play a role in the development and progression of mental illness [23]. In this study, we found that Alu concentration in SZ patients was significantly increased, and ROC analysis also showed that Alu was helpful in assisting the diagnosis of SZ. In addition, we also found that the concentration of cf-DNA in the newly diagnosed patients was higher than which after treatment.

Alu is one of the cell-free DNA detection molecules. Alu sequence is a rich intermediate repeat sequence unique to primate genome, and which is the largest family with short scattered repeat sequences with high homology CG(70-98\%) and can be easily detected. That is dispersed in the whole genome at different densities accounting for $5 \%$ 10\% of the human genome. In other words, three-quarters of all genes in the genome are related to Alu. Environmental or traumatic stress cascades lead to increased Alu expression that leads to inflammation [24]. The alu-centric mechanism has been studied to provide a unified framework for many hypotheses about the origins of neurodegenerative diseases, including inflammation, oxidative stress, metabolic dysfunction, and accumulation of protein bodies [25]. But the relationship between Alu and schizophrenia has been rarely reported.

Studies have shown that the level of cf-DNA in blood is low and stable in healthy people, and the cf-DNA produced by normal tissues is mainly short fragment, usually from apoptotic cells, with a length less than $185 \mathrm{bp}$. While the fragments greater than $10,000 \mathrm{bp}$ are from necrotic cells [26]. Rencent study suggested that there is a higher concentration of short DNA molecules in the schizophrenia patients [29]. In this study, $115 \mathrm{bp}$ fragments were selected as primers to amplify and calculate its content. So, the Alu115 content represented the concentration of cf-DNA in serum.

Cf-DNA has been described in various diseases, including inflammation, tumors, trauma, stroke, myocardial, infarction [26-28]. Longitudinal studies have reported a decrease in the number of cf-DNA in response to therapy and elevations associated with recurrence suggesting that the quantification of cfDNA may contribute to the monitoring of disease status [30,31]. Several studies have proposed the use of cf-DNA in plasma for quantitative detection of colon [31], breast [32], lung cancer [33], etc. The patients with high levels of cf-DNA in plasma either did not respond to treatment or had a higher risk of recurrence [34]. In this study, we found that patients with schizophrenia had higher levels of cf-DNA in their blood than normal controls. The results of the study are consistent with those of Jiang [29] which testified that apoptosis exists in SZ patients and laid the foundation for the evaluation of clinical treatment effect. Our research is supplemented and expanded on this basis. Studies have shown that levels of cf-DNA increase in patients with SZ, which suggest that cf-DNA is ubiquitous in the blood of schizophrenia patients, who suffer from cell apopotisis. And in different schizophrenia subtypes, cf-DNA levels are highest in patients with acute schizophrenia, which suggest that cf-DNA may be associated with the progression of the disease.

In the study, we examined for the potential effect of clinical featrues on change in cf-DNA. We studied the correlation between Alu concentration and clinical characteristics. We found there was no significant 
difference between the serum cf-DNA of SZ patients and the patients' gender, age of onset, duration of disease, treatment time and treatment plan $(P>0.05)$. This suggests that cf-DNA may be an independent indicator at the cellular level relative to these indicators. In addition, we found that there was a statistical difference between Alu and SZ patients' CGI score $(P<0.05)$, but no significant difference with other scores $(P>0.05)$. This result paves the way for studies on the correlation between the concentration of cfDNA and severity of the disease. It is necessary to expand the sample size in the future.

Furthermore, in our study, ROC analysis results showed the AUC was 0.6787 between SZ group and normal control group with a $51.72 \%$ sensitivity and $90 \%$ specificity. ROC to evaluate the diagnostic utility of cf-DNA indicates that serum cf-DNA could serve as a promising marker for SZ diagnosis. In this study, the value of AUC is not very ideal, and the sensitivity and specificity of cf-DNA as a qualified biomarker need to be further improved. Therefore, cf-DNA cannot be used to diagnose schizophrenia alone, and other clinical indicators need to be combined. Based on the above experimental results, we further analyzed the correlation between cf-DNA and clinical data and laboratory examination results.

In this study, we found that apoptosis was common in SZ patients and related to the course of the disease, but the cause of apoptosis in SZ patients has not been determined. By analyzing the correlation between Alu and biochemical indicators in SZ patients, we found that Alu was negatively correlated with RBP and Cyc, positively correlated with NEFA, but not with other indicators, and the r values were all small, indicating that the correlation was not significant. Studies have shown that ApoE in lipoprotein is an endogenous activator of NLRP3 inflamosome [35], which can promote cell apoptosis. In addition, excessive calcium ion outflow may shorten neurite growth and induce nerve cell apoptosis [36], and calcium-mediated cell excitatory toxicity may be an abnormal mechanism leading to SZ cell apoptosis. Therefore, we studied the correlation between Alu and the biochemical indicators. However, no correlation between Alu and $\mathrm{ApoE}$ and $\mathrm{Ca}^{2+}$ was found in the study of clinical biochemical indicators. Although we found a correlation between cf-DNA and RBP, Cyc and NEFA, the mechanism remains to be further studied. Studies have shown that most of the factors released by activated microglia cells in schizophrenia have toxic effects on neurons [37]. Evidence suggests that antipsychotics have neuroprotective potential [38], can inhibit inflammatory responses, combat neuronal damage and reduce cell apoptosis and damage [39-41].

We found that cf-DNA levels underwent dynamic changes after treatment in the primary patients. Moreover, the concentration of cf-DNA was decreased in the post-treatment patients and which was higher than that in healthy individuals. Our results indicate that the detection of serum cf-DNA concentration can evaluate the degree of apoptosis in patients with schizophrenia after antipsychotics treatment, which may related to the occurrence and development of schizophrenia and plays a positive role in evaluating the treatment effect of patients with schizophrenia.

\section{Conclusions}


Our study is to quantify cf-DNA in SZ patients serum by using conventional RT-qPCR with good linearity, specificity and reproducibility. Our results suggest that cf-DNA content is abnormally increased in patients with schizophrenia, which has a good differential value between SZ patients and normal people, and at the same time, which has a certain auxiliary diagnostic significance for the judgment of the efficacy of schizophrenia. As our study was a preliminary report on the clinical value of circulating cf-DNA in SZ, further studies should focus on large-scale sample collection, long-term follow-up, and in-depth functional investigation in order to explore the potential value of cf-DNA in SZ. Cf-DNA could be an ideal biomarker for SZ detection and which has potential clinical value for forecasting prognosis and predicting the therapeutic efficacy for SZ.

\section{Abbreviations}

SZ: schizophrenia; AP: Anti-psychotics; AD: Antidepressants; MS: Mood stabilizers; CGI: Clinical Global Impression; Glu : glucose; CG: glycocholic acid; TBil: total bilirubin; DBil: direct bilirubin; TP: total protein; ALB: albumin; GLO: globulin; ALT: alanine aminotransferase; AST: aspartate aminotransferase; GGT: $\gamma^{-}$ glutamyl transpeptidase; ALP: alkaline phosphatase; LDH: lactic dehydrogenase; HBDH: hydoxybutyrate dehydrogenase; $\mathrm{CK}$ : creatine kinase; CK-MB: creatine kinase MB; CHE: pseudocholinesterase; PA: prealbumin; ADA: adenosine deaminase; BUN: urea nitrogen; CRE: creatinine; UA: uric acid; $\beta 2 M G$ : $\beta 2$ microglobulin; RBP: retinol-binding protein; Cys C: cystatin C; K: kalium; Na: sodium; Cl: chlorinum; Ca: calcium; P: phosphor; Mg: magnesium; CO2: carbon dioxide; CHOL: total cholesterol; TG: triacylglycerol; HDL: high density lipoprotein; LDL: low density lipoprotein; APOA囚: apolipoprotein A囚; APOB: apolipoprotein B; APOE: apolipoprotein E; LP(a): lipoprotein; NEFA: free fatty acid.

\section{Declarations}

\section{Ethics approval and consent to participate}

This study was approved by Nantong Forth People's Hospital ethics committee(2019 K007) and all participants signed an informed consent form. We also asked for written consent from a relative of the acutely psychotic patients.

\section{Consent for publication}

The datas used in the manuscript were agreed by all participants or family members who signed a consent form approved by the institution.

\section{Availability of date and materials}

To protect the identities of the participants, the data used in the manuscript will not be made available to the public.

\section{Competing interests}


The authors declare that they have no competing interests.

\section{Funding}

This study was funded by The Six Talent Peaks Projects of Jiangsu Province (2012-ws-119) and The Health and Planning Project of Nantong (QB201910).

\section{Authors' contributions}

LYC carried out the experiment and wrote the paper, JQ analyzed the date, HLX performed experiments, $\mathrm{XYL}$ collected samples, YJS and SQJ designed the research. All authors have read and approved the manuscript.

\section{Acknowledgements}

The authors would like to thank all the patients who participated in this study for making this study possible.

\section{Authors' information}

Not applicable

\section{References}

1. Halldorsdottir T, Binder EB. Gene $\times$ Environment Interactions: From Molecular Mechanisms to Behavior. Annu Rev Psychol. 2017;68, 215-41.

2. Kahn RS, Sommer IE, Murray RM. Insel TR. Schizophrenia. Nat Rev Dis Primers. 2015; 1, 15067.

3. Chan MK, Krebs MO, Cox D, Guest PC, Yolken RH, Rahmoune H, Rothermundt M, Steiner J, Leweke FM, van Beveren NJ, Niebuhr DW, Weber NS, Cowan DN, Suarez-Pinilla P, Crespo-Facorro B, MamLam-Fook C, Bourgin J, Wenstrup RJ, Kaldate RR, Cooper JD, Bahn S. Development of a blood-based molecular biomarker test for identification of schizophrenia before disease onset. Transl Psychiatry. 2015; 5, e601.

4. Perkovic MN, Erjavec GN, Strac DS, Uzun S, Kozumplik O, Pivac N. Theranostic Biomarkers for Schizophrenia. Int J Mol Sci. 2017; 18(4).

5. Mandel P, Metais P. Les acides nucleiques du plasma sanguin chezl'Homme. C R Seances Soc Biol Fil. 1948; 142(3-4), 241-43.

6. Leon SA, Shapiro B, Sklaroff DM, Yaros MJ. Free DNA in the serum of cancer patients and the effect of therapy.Cancer Res. 1977; 37(3), 646-50.

7. Jiang P, Lo YMD. The Long and Short of Circulating Cell-Free DNA and the Ins and Outs of Molecular Diagnostics. Trends Genet. 2016; 32(6), 360-71.

8. Jahr S, Hentze H, Englisch S, Hardt D, Fackelmayer FO, Hesch RD, Knippers R. DNA fragments in the blood plasma of cancer patients: quantitations and evidence for their origin from apoptotic and 
necrotic cells. Cancer Res. 2001; 61(4), 1659-65.

9. Choi JJ, Reich CF, Pisetsky DS. The role of macrophages in the in vitro generation of extrcellular DNA from apoptotic and necrotic cells. Immunology. 2005; 115(1), 55-62.

10. Horváth S, Mirnics K. Immune system disturbances in schizophrenia. Biol Psychiatry. 2014; 75(4), 316-23.

11. Valerio A, Cardile A, Cozzi V, Bracale R, Tedesco L, Pisconti A, Palomba L, Cantoni O, Clementi E, Moncada S, Carruba MO, Nisoli E. TNF-alpha downregulates eNOS expression and mitochondrial biogenesis in fat and muscle of obese rodents. J Clin Invest. 2006; 116(10), 2791-98.

12. Qiu MJ, Li SC, Jin LZ, Feng PN, Kong YL, Zhao XD, Lin Y, Xu YY, Li CL, Wang WD. Combination of Chymostatin and Aliskiren attenuates ER stress induced by lipid overload in kidney tubular cells. Lipids Health Dis. 2018; 17: 183.

13. Li J. Neuroprotective effect of (-)-epigallocatechin-3-gallate on autoimmune thyroiditis in a rat model by an anti-inflammation effect, anti-apoptosis and inhibition of TRAIL signaling pathway. Exp Ther Med. 2018; 15(1): 1087-92.

14. Oppenheim RW. Cell death during development of the nervous system. Annu. Rev. Neurosci. 1991; 14, 453-01.

15. Jarskog LF, Selinger ES, Lieberman JA, Gilmore JH. Apoptotic proteins in the temporal cortex in schizophrenia: high Bax/Bcl-2 ratio without caspase-3 activation. Am J Psychiatry. 2004; 161(1), 109-15.

16. Jarskog LF, Gilmore JH, Selinger ES, Lieberman JA. Cortical bcl-2 protein expression and apoptotic regulation in schizophrenia. Biol Psychiatry. 2000; 48(7), 641-50.

17. Meier MH, Shalev I, Moffitt TE, Kapur S, Keefe RSE, Wong T, Belsky DW, Harrington HL, Hogan S, Houts R, Caspi A, Poulton R. Microvascular abnormality in schizophrenia as shown by retinal imaging. Am J Psychiatry. 2013; 170(12), 1451-9.

18. Uranova NA, Zimina IS, Vikhreva OV, Krukov NO, Rachmanova VI, Orlovskaya DD. Ultrastructural damage of capillaries in the neocortex in schizophrenia. World J Biol Psychiatry. 2010; 11(3), 567-78.

19. Sinka L, Kovari E, Santos M, Herrmann FR, Gold G, Hof PR, Bouras C, Giannakopoulos P. Microvascular changes in late-life schizophrenia and mood disorders: stereological assessment of capillary diameter in anterior cingulate cortex. Neuropathol Appl Neurobiol. 2012; 38(7), 696-09.

20. Jaskog LF, Glantz LA, Gilmore JH, Lieberman JA. Apoptotic mechanisms in the pathophysiology of schizophrenia. Prog. Neuropsychopharmacol. Biol. Psychiatry. 2005; 29(5), 846-58.

21. Wang BG, Huang HY, Chen YC, Bristow RE, Kassauei K, Cheng CC, Roden R, Sokoll LJ, Chan DW, Shih Increased plasma DNA integrity in cancer patients. Cancer Res. 2003; 63(14), 3966-8.

22. Umetani N, Kim J, Hiramatsu S, Reber HA, Hines OJ, Bilchik AJ, Hoon DSB. Increased integrity of free circulating DNA in sera of patients with colorectal or periampullary cancer: direct quantitative PCR for ALU repeats. Clin Chem. 2006; 52(6), 1062-9. 
23. Hartwig FP, Borges MC, Horta BL, Bowden J, Smith GD. Inflammatory Biomarkers and Risk of Schizophrenia: A 2-Sample Mendelian Randomization Study. JAMA Psychiatry. 2017; 74(12): 122633.

24. Li TH., Schmid CW. Differential stress induction of individual Alu loci: implications for transcription and retrotransposition. Gene. 2001; 276, 135-41.

25. Larsen PA., Hunnicutt KE, Larsen RJ, Yoder AD, Saunders Warning SINEs: Alu elements, evolution of the human brain, and the spectrum of neurological disease. Chromosome Res. 2018; 26(1-2), 93-11.

26. Giacona MB, Ruben GC, Iczkowski KA, Roos TB, Porter DM, Sorenson GD. Cell-free DNA in human blood plasma: length measurements in patients with pancreatic cancer and healthy controls. Pancreas. 1998; 17(1), 89-97.

27. Schwarzenbach H, Hoon DS, Pantel K. Cell-free nucleic acids as biomarkers in cancer patients. Nat Rev Cancer. 2011; 11(6), 426-37.

28. Wan JCM, Massie C, Garcia-Corbacho J, Mouliere F, Brenton JD, Caldas C, Pacey S, Baird R, Rosenfeld N. Liquid biopsies come of age: towards implementation of circulating tumour DNA. Nat Rev Cancer. 2017; 17(4), 223-38.

29. Jiang J, Chen XL, Sun LY, Qing Y, Yang XH, Hu XW, Yang C, Xu TL, Wang JJ, Wang P, He L, Dong CQ, Wan CL. Analysis of the concentrations and size distributions of cell-free DNA in schizophrenia using fluorescence correlation spectroscopy. Transl Psychiatry. 2018; 8 (1), 104-12.

30. Dawson SJ, Tsui DW, Murtaza M, Biggs H, Rueda OM, Chin SF, Dunning MJ, Gale D, Forshew T, Mahler-Araujo B, Rajan S, Humphray S, Becq J, Halsall D, Wallis M, Bentley D, Caldas C, Rosenfeld N. Analysis of circulating tumor DNA to monitor metastatic breast cancer. N Engl J Med. 2013; 368(13), 1199-09.

31. Frattini M, Gallino G, Signoroni S, Balestra D, Battaglia L, Sozzi G, Leo E, Pilotti S, Pierotti MA. Quantitative analysis of plasma DNA in colorectal cancer patients: a novel prognostic tool. Ann N Y Acad Sci. 2006; 1075, 185-90.

32. Hashad D, Sorour A, Ghazal A, Talaat I. Free circulation tumor DNA as a diagnostic marker for breast cancer. J Clin Lab Anal. 2012; 26(6), 467-72.

33. Paci M, Maramotti S, Bellesia E, Formisano D, Albertazzi L, Ricchetti T, Ferrari G, Annessi V, Lasagni D, Carbonelli C, Franco SD, Brini M, Sgarbi G, Lodi R. Circulating plasma DNA as diagnostic biomarker in non-small cell lung cancer. Lung Cancer. 2009; 64(1), 92-7.

34. Catarino R, Ferreira MM, Rodrigues $H$, Coelho A, Noqal A, Sousa A, Medeiros R. Quantification of free circulation tumor DNA as a diagnostic marker for breast cancer. DNA Cell Biol. 2008; 27(8), 415-21.

35. Wang RQ, Wang YQ, Mu NN, Lou XY, Li WX, Chen YM, Fan D, Tan HM. Activation of NLRP3 inflammasomes contributes to hyperhomocysteinemia-aggravated inflammation and atherosclerosis in apoE-deficient mice. Lab Invest. 2017; 97(8): 922-34.

36. Segal M, Korkotian I, Murphy DD. Dendritic spine formation and pruning: common cellular mechanisms? Trends Neurosci. 2000; 23(2), 53-7. 
37. Fernandes A, Miller-Fleming L, Pais TF. Microglia and inflammation: conspiracy, controversy or control? Cell Mol Life Sci. 2014; 71(20): 3969-85.

38. Jeffrey A, Lieberman JA, Frank P, Bymaster FP, Herbert Y, Meltzer HY, Ariel Y. Antipsychotic Drugs: Comparison in Animal Models of Efficacy, Neurotransmitter Regulation, and Neuroprotection. Pharmacol Rev. 2008; 60(3): 358-03.

39. Lipska BK, Jaskiw GE, Weinberger DR. Postpubertal emergence of hyperresponsiveness to stress and to amphetamine after neonatal excitotoxic hippocampal damage: a potential animal model of schizophrenia. Neuropsychopharmacology. 1993; 9(1): 67-75.

40. Lipska BK, Weinberger DR. To model a psychiatric disorder in animals: schizophrenia as a reality test. Neuropsychopharmacology. 2000; 23(3): 223-39.

41. Hill RA. Sex differences in animal models of schizophrenia shed light on the underlying pathophysiology. Neurosci Biobehav Rev. 2016; 67: 41-56.

\section{Figures}

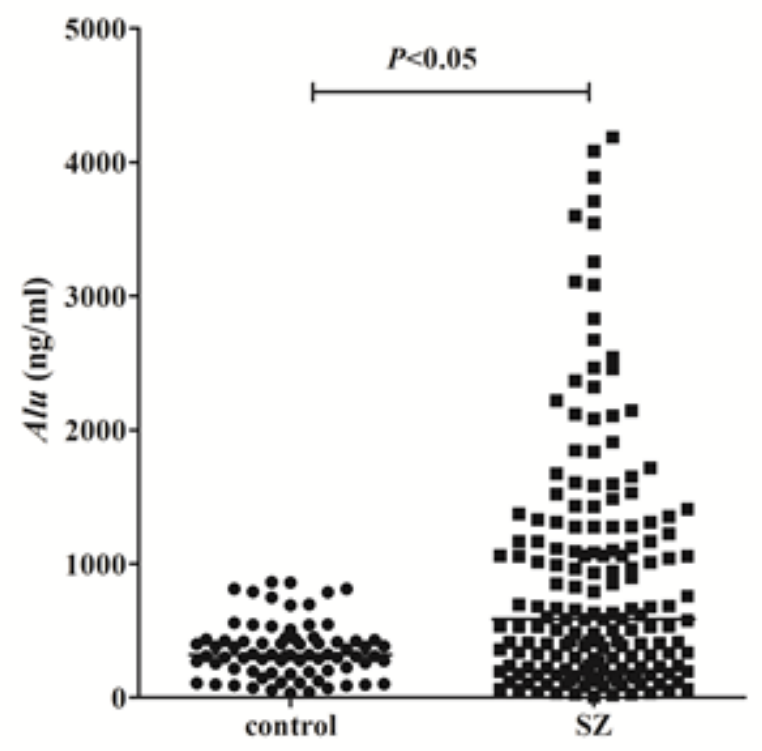

Figure 1

cf-DNA levels measured by RT-qPCR. Statistical comparisons were performed using logistic analysis. When P-value $<0.05$, the difference was statistically significant. The horizontal line represents the median for each group. 


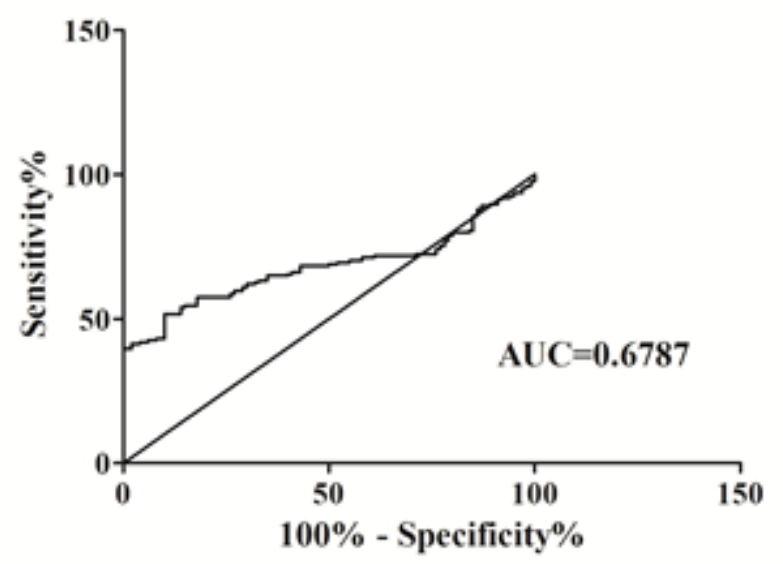

Figure 2

The ROC analysis of Alu between SZ patients and healthy controls. RT-qPCR and ROC curve analysis for predicting cf-DNA as a SZ diagnosis biomarker. The area under the curve (AUC) value was 0.6787 .

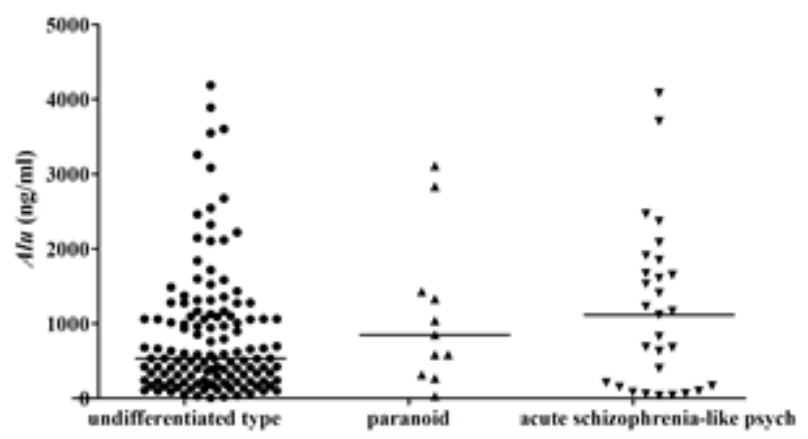

\section{Figure 3}

Scatter plot of serum Alu from patients with different types of schizophrenia. SZ patients were divided into undifferentiated type (133), paranoid (11), acute schizophrenia-like psychosis (29), and other subtypes (2), no statistical differences between different classification groups $(P>0.05)$.

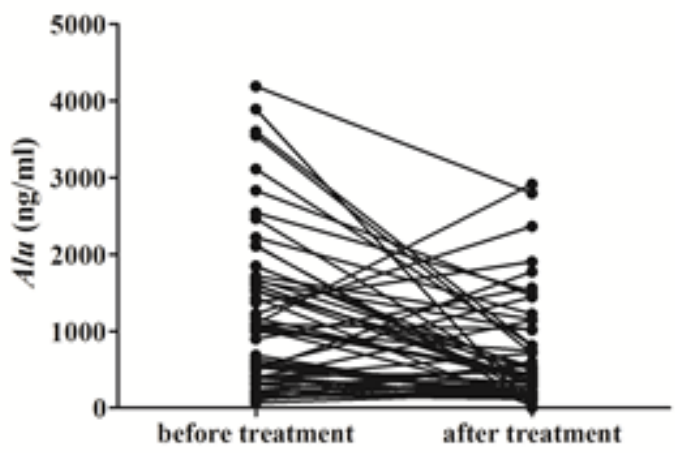


Figure 4

RT-qPCR analysis for predicting cf-DNA as a SZ prognosis biomarker. Line chart of serum cf-DNA levels monitored in the 57 primary SZ patients. The different dots represent the individual subjects and the lines connect the baseline value to the corresponding follow-up. 